\title{
Age Diversity and Corporate Social Responsibility-Evidence from Chinese Listed Firms
}

\author{
Pu Liu, Runjia Zeng* \\ School of Economics, Jinan University, Guangzhou, China \\ Email: lpgauss@163.com, *locke1993@163.com
}

How to cite this paper: Liu, P. and Zeng, R.J. (2017) Age Diversity and Corporate Social Responsibility_Evidence from Chinese Listed Firms. Open Journal of Social Sciences, 5, 1-8.

https://doi.org/10.4236/jss.2017.54001

Received: March 14, 2017

Accepted: April 11, 2017

Published: April 14, 2017

Copyright $\odot 2017$ by authors and Scientific Research Publishing Inc. This work is licensed under the Creative Commons Attribution International License (CC BY 4.0).

http://creativecommons.org/licenses/by/4.0/

\begin{abstract}
The impact of diversification of corporate governance on corporate performance has been the focus of multiple parties, the age constitution of the board and the presentation of corporate social responsibility have brought new ideas to this problem. This article examines whether the age diversity of board hinders the implementation of CSR. We select 305 Chinese listed firms' annual data from 2010 to 2014, and use ordinary least squares method and twostage least squares method to investigate the effect. We find the age diversity is negatively associated with the CSR performance, which is consistent with the analysis based on social psychology.
\end{abstract}

\section{Keywords}

Corporate Governance, Corporate Social Responsibility, Age Diversity, Social Psychology

\section{Introduction}

The "stock disaster" occurred in China in 2015, making firms' fundamentals become the focus. New Institutional Economics argues the institution is critical to the performance of economic organizations, and that the improvement in corporate performance requires a better design of corporate governance structures. So it is inevitable to answer how the company's performance measures.

Based on the Friedman equity maximization theory, traditional corporate finance argues that firm performance is to maximum the residual claim of stockholders, which has been questioned by follow-up scholars [1] [2]. They point out the enterprise is "a nexus of contracts", it is an economic network grouped by creditors, employees, suppliers and other stakeholders, so corporate perfor- 
mance should reflect the common interests of stakeholders. Then, Siegel (2007) points out that Corporate Social Responsibility is a natural tool to measure common interests of stakeholders [3], which makes us available to use CSR to measure firm performance.

In practice, CSRC, SSE and SZSE have promulgated laws and regulations to require enterprises to disclose social responsibility information, at the same time, the BCC, Sinopec and Baidu Group have begun to set up social responsibility committee. All these facts undoubtedly show that corporate social responsibility, as a basic principle of the distribution of internal rights within the company, have begun to be concerned by the Chinese government and business managers.

Therefore, the incorporation of corporate social responsibility into the study of corporate performance is of great significance to the practical and theoretical circles. But the fulfillment of CSR ultimately requires the decision-making of the board, and the decision-making depends on the constitute structure of the board members. So it is of practical significance to examine the relationship between the structure of the board members and corporate social responsibility. This paper intends to examine the impact of the age diversity of board on corporate social responsibility.

The rest of this paper is organized in the following structure. In the next section, we discuss the existing literature about board diversity and CSR and develop our hypotheses. In the following section, we discuss our data and sample statistics. Then, we conduct and discuss our empirical research and robustness checks. Finally, we summary the main findings and provide some suggestions.

\section{Literature Review and Hypotheses}

\subsection{Literature Review}

The impact of corporate governance on corporate performance has been the focus of multi-parties. In the study of corporate governance, most scholars believe its core is to design corporate governance structure with minimal agency costs to constrain managers to achieve corporate value creation [4]. The board is a kind of institute with the type of feature, so the existing of board is critical to corporate performance. And the power of board depends on its constitution, it is necessary to investigate the relationship between board diversity and corporate performance. Erhardt (2003) pointed out the gender diversity can improve corporate financial performance [5]; Adams (2009) pointed out if using the ROA as a measure of corporate performance, the gender diversity will significantly reduce corporate performance [6]; Francoeur (2008) analyzed the effect between the gender diversity and corporate performance based on the Fama \& French Valuation Model, and pointed out that no having significant relationship between gender diversity and corporate performance [7].

Domestic scholars also use the data of Chinese listed companies to study the impact of board diversity on corporate performance. Kuang (2012) found that gender diversity is negatively associated with corporate performance [8]; Huang 
(2015) pointed out that the proportion of female directors in the board can significantly affect firms' supervision, and thus improve corporate performance [9].

By combing the literatures in this field, we find the effect of board diversity on corporate performance is still in dispute. This controversy stems from two reasons: the measurement of board diversity and corporate performance. The existing literatures mainly adopt gender diversity in measuring board diversity, and the measurement of firm performance is mainly based on the Shareholder Wealth Maximization Theory.

Follow-up scholars launch discussion around these two defects. The amendment to the second defect comes from the Stakeholder's presentation. Based on the theory, corporate performance is no longer just to maximize shareholder wealth, but to balance the interests of various stakeholders, namely to optimize CSR management [10] [11]. And the amendment for the first aspect is mainly seen in some sporadic empirical research. Harjoto (2015) introduced comprehensive diversity to measure the board diversity [12].

Sorting out the literatures, this paper will continue to examine the impact of board diversity on corporate performance. We will use age diversity to measure board diversity, and adopt CSR to measure corporate performance.

\subsection{Hypotheses}

The Social Psychology argues that people tend to hate people or things that are different from their own, and when anybody who is different from them enters the group, the group will show a process of resistance. People in the organization will be less communication and cooperation with new comers, they will shield information and knowledge from new entrants, and they will also intensify the conflict with the entrants, so as to achieve the purpose of isolating entrants. Finally, it will lead to higher turnover and inefficiency in organizations with a higher degree of diversity.

When age diversity is higher in board, the heterogeneity between the members will become more serious, the degree of recognition and integration between members will be deepened, the controversy over the board issues will be intensified, and the compromise will be impossible. Corporate social responsibility is a new type of corporate governance objectives, because of its immaturity, board members will have more disputes at the beginning of its implementation, bur the age diversity among members deepened the initial dispute, it will delay the implementation and management of CSR finally. So age diversity will reduce the CSR performance.

Hypothesis Ceteris paribus, age diversity in corporate board is negatively associated with CSR performance.

\section{Data and Sample}

\subsection{Sample Construction}

The sample for this paper utilizes the CSMAR database from 2010 to 2014, we 
select 305 A-share listed firm's annual data to construct AGE and CSR. During the selecting, we exclude following sample firms: 1) ST and ST*; 2) financial indicators are missed in sample area; 3 ) companies in the integrated industry, instrumentation, and radio and television and audio and video industries; 4) companies that are delisted in the sample area; 5) financial companies. Eventually, we gather 1520 observations from 2010 to 2014, since we use a 1-year lag on the diversity and CSR measures to account for serial correlation, our final sample consists of 1215 observations across 305 firms from 2010 to 2014.

\subsection{Constructing Age Diversity and CSR Measures}

We use Blau's index of heterogeneity, calculated as $1-\sum P_{i}^{2}$, where $P$ is the proportion of directors in a category and $i$ is the number of categories, to calculate the age diversity (AGE). AGE is the index of heterogeneity for director age with four categories: 35 to 45,45 to 55, 55 to 65 and 65-years old and older.

AGE index takes on values between zero and one. As index has a value of zero when there is only category within age dimension, suggesting that group is perfectly heterogeneous. Age index value closer to one suggests a more heterogeneous group.

We use index method to measure CSR. Based on CSMAR, it divide corporate's social responsibility into twelve categories, then assign value to each item, if some an item exists, assign one to it, otherwise 0 . Eventually summary these values to calculate CSR. But we partly modify the calculation by introducing other two numerical indicators on the basis of CSMAR: social contribution value of each equity and social donation (assign 2 to it if existing, otherwise 0 ), then we summary fourteen item to get overall CSR index.

\subsection{Control Variables}

We run several regressions of CSR on AGE and a set of control variables that have been found significantly affecting firms' CSR on the existing literatures. Based on McWilliams and Siegel [13], we control ASSET; Jo (2011) finds that CSR is affected by SALEGRW [14]; Campbell (2007) argues that firms' CSR is negatively associated with firms' risk (TOTRISK) [15]; Zhang (2013) points out that Tobin's Q is an important factor for CSR [11]; Harjoto (2015) also finds that RET is necessary to CSR. Table 1 demonstrates these control variables and their definitions [12].

\subsection{Sample Statistics}

Table 2 presents the descriptive statistics for our sample. Our sample firms have an average CSR score of 9.31, which is at the middle level relative to the total score, suggesting the implementation of CSR in domestic enterprises is relatively lack. And the AGE average score is 0.57 , which suggests diversity is more homogeneous in age.

The average firm in our sample has an ASSET value of 10.10 or about 2.4 billion Yuan, and has a sales growth (SALEGRW) of 0.46 percent of net sales. The 
average firm has a Tobin $\mathrm{Q}$ of 1.23, suggesting that its market value is higher than their book value. During our sample period, the average annual stock return (RET) is $9.12 \%$, and has an average volatility of daily stock return (TOT-RISK).

Table 3 provides the correlations of CSR, AGE and control variables. We find the AGE is negatively associated with CSR, and the signs between CSR and other control variables are not consistent with we expected, we will continue to examine it.

Table 1. Control variables definitions.

\begin{tabular}{ccc}
\hline Variables & Expected signs on CSR & Definitions \\
\hline ASSET & + & Natural log of total asset \\
SALEGRW & $?$ & $\begin{array}{c}\text { Annual growth of the sales } \\
\text { TOBINQ }\end{array}$ \\
TOTRISK & - & $\begin{array}{c}\text { Tobin's Q ratio calculated as the book value of } \\
\text { assets minus the book value of equities plus the } \\
\text { market value of equities, divided by the book } \\
\text { value of assets }\end{array}$ \\
RET & + & $\begin{array}{c}\text { Standard deviation of daily stock return in } 1 \text { year } \\
\text { Annual stock return during the year }\end{array}$ \\
\hline
\end{tabular}

Table 2. Descriptive statistics.

\begin{tabular}{ccccccc}
\hline Variables & Obs. & Mean & Std. dev. & Min & Medium & Max \\
\hline CSR & 1215 & 9.31 & 2.04 & 2.00 & 9.00 & 15.00 \\
AGE & 1215 & 0.57 & 0.13 & 0.00 & 0.59 & 0.81 \\
ASSET & 1215 & 10.10 & 0.67 & 8.49 & 10.04 & 12.38 \\
SALEGRW & 1215 & 0.46 & 1.70 & -0.86 & 0.09 & 22.74 \\
TOBINQ & 1215 & 1.23 & 1.15 & 0.09 & 0.85 & 8.20 \\
RET & 1215 & 9.12 & 44.80 & -64.42 & -1.11 & 254.94 \\
TOTRISK & 1215 & 2.47 & 1.48 & 0.84 & 2.38 & 47.86 \\
\hline
\end{tabular}

Table 3. Correlation coefficients.

\begin{tabular}{ccccccccc}
\hline No. & Variables & 1 & 2 & 3 & 4 & 5 & 6 & 7 \\
\hline 1 & CSR & 1.00 & & & & & & \\
2 & AGE & $-0.08^{*}$ & 1.00 & & & & & \\
3 & ASSET & $0.17^{*}$ & 0.05 & 1.00 & & & & \\
4 & SALEGRW & $-0.08^{*}$ & 0.03 & $0.02^{*}$ & 1.00 & & & \\
5 & TOBINQ & $-0.03^{*}$ & $-0.03^{*}$ & $-0.55^{*}$ & $-0.05^{*}$ & 1.00 & & \\
6 & RET & -0.06 & 0.13 & 0.09 & $0.07^{*}$ & $0.10^{*}$ & 1.00 & \\
7 & TOTRISK & $-0.00^{*}$ & -0.14 & 0.06 & $-0.02^{\star}$ & $0.00^{*}$ & $0.01^{\star}$ & 1.00 \\
\hline
\end{tabular}

* Statistically significant at $10 \%$ level or less. 


\section{Result and Analysis}

\subsection{Regression and Analysis}

We examine the impact of AGE on CSR using the multivariate regression analysis and controlling for other factors that have been found significantly affecting CSR in prior research. Since CSR tends to be unchanged over time, there is a potential serial correlation between the current CSR and the previous CSR. We include the lag effect of CSR $\left(C S R_{-1}\right)$ to control for the potential serial correlation.

Table 4 reports the regression results based on the ordinary least square (OLS) and two-stage least square. We find a serial correlation between the current CSR and the previous period CSR. The coefficients of the lag effect of the CSR measures are statistically significant and close to one during OLS regression. In the first three columns of Table 4, we examine the impact of the AGE on CSR based on the OLS regression. We find that AGE is negatively associated with CSR, and the coefficient is significant, which is consistent with the analysis based on the social psychology, and supports the Hypothesis.

In the last three columns of Table 4, we examine the impact of the AGE on CSR based on the two-stage least square regression. We find the result between AGE and CSR is consistent with OLS regression, which further confirms our Hypothesis.

We find the impacts of control variables are generally consistent with the findings in existing studies. Total assets (ASSET) and stock return (RET) are positively associates with CSR because larger and more profitable firms have more resources available to engage in CSR activities. We also find that firms with higher volatility stock returns (TOTRISK) have lower CSR. Consistent with Zhang (2013), we find that Tobin's Q has a positively correlation with CSR.

\subsection{Robustness Tests}

We conduct several robustness tests. First, we examine whether our results hold using different measures of CSR, we adopt the CSR based on CSMAR database to conduct the test. Second, we examine whether our results hold using a different sample, we divide our sample into two group based on HHI to conduct the test.

Table 5 presents the robustness tests results, the first two columns report the result based on CSMAR database's CSR, the middle two columns analyze the effect in high HHI industry, and the last two columns report the results from low $\mathrm{HHI}$ industry. We find all the results are consistent with our OLS and two-stage least square regression results, which suggest our analysis is robust.

\section{Conclusions}

Board diversity and CSR have become two pressing issues for publicly held corporations. Regulators are urging companies to improve board diversity, at the same time, stakeholder and public are demanding companies to undertake more 
Table 4. Regression results.

\begin{tabular}{ccccccc}
\hline & \multicolumn{5}{c}{ CSR } \\
\cline { 2 - 7 } Variables & \multicolumn{5}{c}{ Model (1) } & \multicolumn{3}{c}{ Model (2) } \\
\cline { 2 - 7 } & Coefficient & t-value & P-value & Coefficient & t-value & P-value \\
\cline { 2 - 7 } CSR & $0.65^{* * *}$ & 30.03 & 0.00 & $0.16^{* * *}$ & 29.31 & 0.00 \\
AGE & $-0.89^{* * *}$ & -2.65 & 0.01 & $-1.09^{* * *}$ & -3.05 & 0.00 \\
ASSET & $0.31^{* * *}$ & 3.91 & 0.00 & $0.29^{* *}$ & 2.32 & 0.02 \\
SALEGRW & $-0.09^{* * *}$ & -3.37 & 0.00 & $-0.09^{* * *}$ & -3.35 & 0.00 \\
TOBINQ & $0.08^{*}$ & 1.67 & 0.10 & $0.10^{*}$ & 1.81 & 0.07 \\
TOTRISK & -0.04 & -1.56 & 0.14 & $-0.06^{*}$ & -1.66 & 0.10 \\
RET & -0.00 & -0.6 & 0.59 & $0.03^{*}$ & -1.72 & 0.09 \\
Constant & 0.85 & 1.00 & 0.32 & $2.12^{* *}$ & 2.32 & 0.03 \\
$\mathrm{R}^{2}$ & & 0.46 & & & 0.19 & \\
Observations & & 1215 & & & 305 & \\
\# Firms & & 305 & & & 305 \\
\hline
\end{tabular}

Model (1) represents the OLS regressions, and Model (2) indicates the Two-Stage Least Square regression. All regressions include the CSEC 51 industries and year fixed effects. ${ }^{*},{ }^{*},{ }^{* *}$ indicate statistically significant at 10,5 and $1 \%$, respectively.

Table 5. Robustness Tests.

\begin{tabular}{|c|c|c|c|c|c|c|}
\hline \multirow{3}{*}{ Variables } & \multicolumn{6}{|c|}{ CSR } \\
\hline & \multicolumn{2}{|c|}{ Test 1} & \multicolumn{2}{|c|}{ Test 2} & \multicolumn{2}{|c|}{ Test 3} \\
\hline & Coefficient & $\mathrm{t}$-value & Coefficient & t-value & Coefficient & $\mathrm{t}$-value \\
\hline$C S R_{-1}$ & $0.79^{* * *}$ & 50.80 & $0.62^{\star * \star}$ & 19.31 & $0.67^{* * *}$ & 22.55 \\
\hline AGE & $-0.15^{\star}$ & -1.67 & -0.66 & -1.30 & $-1.09^{\star *}$ & -2.47 \\
\hline Constant & $1.19^{* * *}$ & 2.66 & $2.87^{* *}$ & 2.15 & -0.30 & 0.51 \\
\hline $\begin{array}{c}\text { Control } \\
\text { Variables }\end{array}$ & \multicolumn{2}{|l|}{ Yes } & \multicolumn{2}{|c|}{ Yes } & \multicolumn{2}{|c|}{ Yes } \\
\hline $\mathrm{R}^{2}$ & \multicolumn{2}{|l|}{0.69} & \multicolumn{2}{|c|}{0.42} & \multicolumn{2}{|c|}{0.51} \\
\hline Observations & \multicolumn{2}{|l|}{1215} & \multicolumn{2}{|c|}{602} & \multicolumn{2}{|c|}{613} \\
\hline
\end{tabular}

Test 1 presents the Robustness test by adjusting CSR's measurement, Test 2 and Test 3 test High HHI industry as well as Low HHI industry respectively. All regressions include the CSEC 51 industries and year fixed effects, ${ }^{*}, * *, * *$ indicate statistically significant at 10,5 and $1 \%$, respectively.

social responsibility. Our study examines the impact of age diversity on CSR, we find age diversity will reduce the implementation of CSR, which is consistent with the analysis based on the social psychology. So it is necessary to neutralize the age gap between the board members in the process of board diversity reforms.

Our study contributes to the greater understanding of the role of board diversity in overseeing management performance. However, we only examine the effects of age diversity, it is necessary to introduce a more comprehensive board diversity induce to conduct further research. 


\section{References}

[1] Freeman, E. (1984) Strategic Management: A Stakeholder Approach. Cambridge University Press, Boston.

[2] Cornell, B. and Shapiro, A. (1987) Corporate Stakeholders and Corporate Finance. Financial Management,16, 5-14. http://www.jstor.org/stable/3665543

[3] Siegel, D. and Vitaliano, D. (2007) An Empirical Analysis of the Strategic Use of Corporate Social Responsibility. Journal of Economics \& Management Strategy, 16, 773-792. https://doi.org/10.1111/j.1530-9134.2007.00157.x

[4] Jensen, M. and Meckling, W. (1976) Theory of the Firm: Managerial Behavior, Agency Costs and Ownership Structure. Journal of Financial Economics, 3, $305-$ 360. http://citeseer.ist.psu.edu/showciting?cid=12378354

[5] Erhardt, N., Werbel, J. and Shrader, C. (2003) Board of Director Diversity and Firm Financial Performance. Corporate Governance: An International Review, 11, 102111. https://doi.org/10.1111/1467-8683.00011

[6] Adam, R. and Ferreria, D. (2009) Women in the Boardroom and Their Impact on Governance and Performance. Journal of Finance Economics, 2, 291-309.

[7] Francoeur, C. and Labelle, R. (2008) Gender Diversity in Corporate Governance and Top Management. Journal of Business Ethics, 81, 83-95. https://doi.org/10.1007/s10551-007-9482-5

[8] Kuang, X.W, Peng, D.Y. and Lin, N. (2012) Does the Female Director Improve the Company's Financial Performance? Empirical Evidence from Chinese Listed Firms. Jiangxi Social Science, 4, 218-223.

[9] Huang, Z.Z., Xue, Q.M. and Su, L. (2015) Female Director, CEO Turnover and Firm Performance: Evidence from Chinese Listed Firms. Economic Review, 6, 132-143.

[10] Benson, B.W. and Dividson, W.N. (2010) The Relation between Stakeholder Management, Firm Value and CEO Compensation: A Test of Enlightened Value Maximization. Financial Management, 3, 929-964.

http://www.blackwell-synergy.com/doi/abs/10.1111/j.1755-053X.2010.01100.x https://doi.org/10.1111/j.1755-053X.2010.01100.x

[11] Zhang, Z.G., Jin, X.C. and Li, G.Q. (2013) An Empirical Study on the Interactive and Inter-Temporal Influence between Corporate Social Responsibility and Corporate Financial Performance. Accounting Study, No. 8, 218-223.

http://www.cnki.com.cn/Article/CJFDTotal-KJYJ201308005.htm

[12] Harjoto, M., Laksmana, I. and Lee, R. (2015) Board Diversity and Corporate Social Responsibility. Journal of Business Ethics, 132, 641-660. https://doi.org/10.1007/s10551-014-2343-0

[13] McWilliams, A. and Siegel, D. (2001) Corporate Social Responsibility: A Theory of the Firm Perspective. The Academy of Management Review, 26, 117-127. http://www.jstor.org/stable/259398

[14] Jo, H. and Harjoto, M. (2011) Corporate Governance and Firm Value: The Impact of Corporate Social Responsibility. Journal of Business \& Ethics, 103, 351-383. https://doi.org/10.1007/s10551-011-0869-y

[15] Campbell, L. (2007) Why Would Corporations Behave in Socially Responsible Ways? An Institutional Theory of Corporate Social Responsibility. The Academy of Management Review, 32, 946-967. http://www.jstor.org/stable/20159343 https://doi.org/10.5465/amr.2007.25275684 
Submit or recommend next manuscript to SCIRP and we will provide best service for you:

Accepting pre-submission inquiries through Email, Facebook, LinkedIn, Twitter, etc. A wide selection of journals (inclusive of 9 subjects, more than 200 journals)

Providing 24-hour high-quality service

User-friendly online submission system

Fair and swift peer-review system

Efficient typesetting and proofreading procedure

Display of the result of downloads and visits, as well as the number of cited articles Maximum dissemination of your research work

Submit your manuscript at: http://papersubmission.scirp.org/

Or contact jss@scirp.org 